\title{
Historein
}

Vol 15, No 1 (2015)

Revisiting Democratic Transitions in Times of Crisis

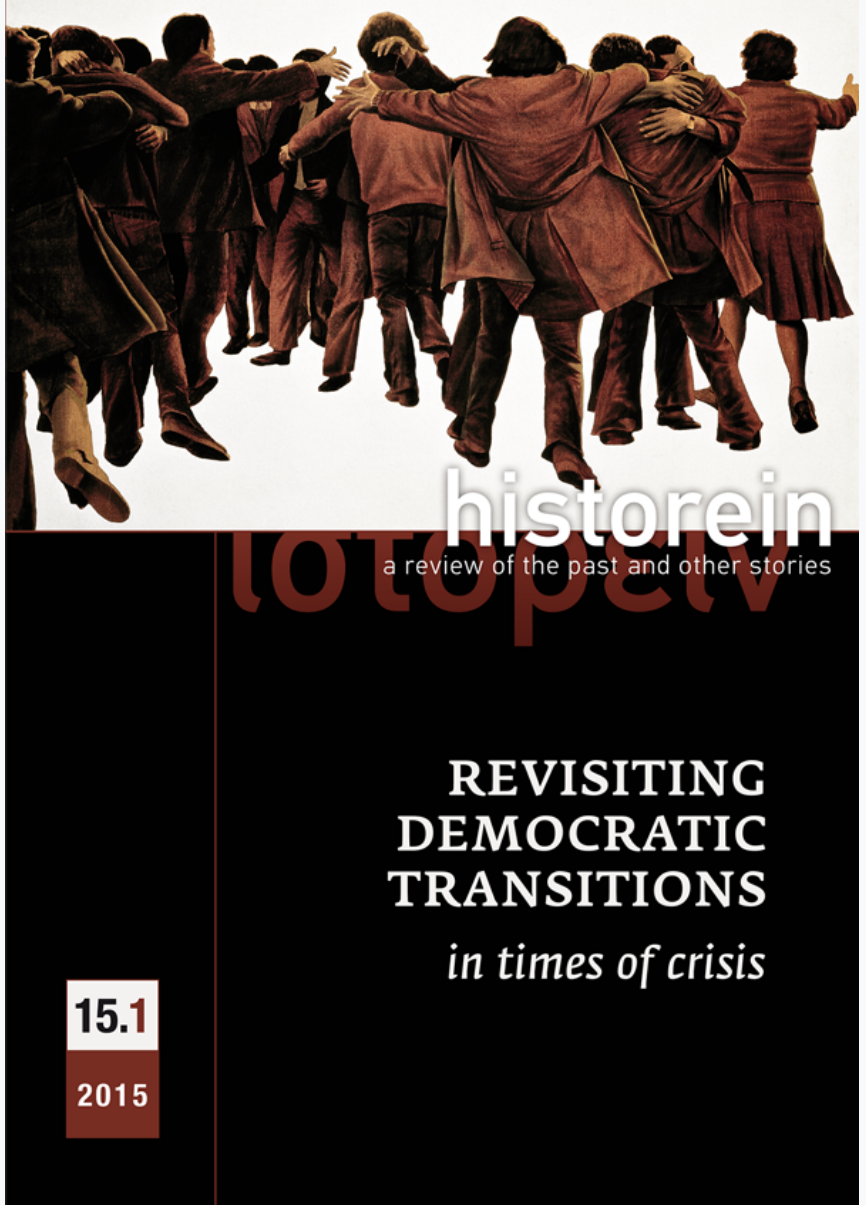

Introduction: The end of a parable? Unsettling the transitology model in the age of crisis

Kostis Kornetis

doi: $10.12681 /$ historein.322

Copyright (C) 2015, Kostis Kornetis

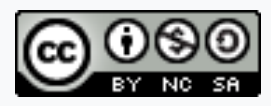

This work is licensed under a Creative Commons Attribution-NonCommercialShareAlike 4.0.

To cite this article:

Kornetis, K. (2015). Introduction: The end of a parable? Unsettling the transitology model in the age of crisis. Historein, 15(1), 5-12. https://doi.org/10.12681/historein.322 


\section{The end of a parable? Unsettling the transitology model in the age of crisis}

The present volume is partly the product of a multidisciplinary conference that took place in Berlin in 2013. The conference, co-sponsored by Historein, the Free University of Berlin and New York University, intended to look at transitions in a comparative and transnational perspective, also in terms of theory and memory, in an attempt to update our analytical lexicon regarding these processes. The main idea was that the "Great Recession" that began in 2008 created a sense of urgency to reassess postauthoritarian and postautocratic phenomena. From a southern European vantage point, in particular, we could safely argue that this urgency is due to the conviction that those societies in the region that underwent the so-called third wave to democracy' are currently experiencing the end of a parable and an entire paradigm: as the social contracts that were, to a great extent, fostered in the aftermath of the dictatorships are collapsing, the idea of the transitions as smooth examples of political realism and masterful engineering is also evaporating. Greece and Spain, notably, were considered as paradigmatic cases of a "smooth transition", whose lessons could be allegedly applied elsewhere, in contexts as diverse as those of Uruguay, Poland, Hungary and South Africa. ${ }^{2}$ Even these "model" transitions are no longer regarded as transparent and exemplary processes - and the current volume helps us comprehend how fragile and contingent their outcomes really were, as neither civilians nor institutions had absolute control over them. ${ }^{3}$

At the same time that the social welfare par-

\section{Introduction} adigm is nearly over in the European South, there is a widespread sense of a structural connection between current politics and political transitions - as parts of the same historical cycle that is now coming to a close. Resurging memories, political slogans, historical metaphors and past conceptual frames express the conflict between collective experience and official historical narratives, and the distance between expectations and practices, poetics and politics, history and memory, state policies and everyday life. Part of the current symbols of antiausterity protest, for instance, stem from the period of the dictatorships, the transitions and their poetical-popular archive: protesters interrupted a speech by Portuguese prime minister Pedro Passos Coelho in the national assembly in February 2013 by singing "Grândola, Vila Morena", Zeca Afonso's emblematic song that gave the signal for the Portuguese revolution in 1974. Guya Accornero mentions other uses of the song by protesters in strikes in her piece on the "austere" 40th anniversary of the revolution and the appearance of so-called "new" new social movements, as a direct implementation of José Saramago's appeal to "turn every citizen into a politician". At the same time, however, that "task of remembering the past makes everyone his [or 
her] own historian" too - to quote the famous phrase by Pierre Nora. ${ }^{4}$ Two years earlier, in the summer of 2011, the Greek indignados, who called for an inclusive and fully participatory democracy, rhythmically chanted "Bread-Education-Freedom", the main slogan of the student protesters in the November 1973 uprising against the Colonels' dictatorship, adding “The junta did not end in 1973", thus indicating a certain continuity in state coercion from the 1970s to the present and the persistence of authoritarian legacies. ${ }^{5}$ In Spain, a graffito that proliferated during antiausterity protests was "Franco is back", rather than "Franco is dead", which was the famous television communiqué by prime minister Carlos Arrias Navarro in November 1975 - as analysed by Germán Labrador Méndez in his article on the collective hijackings of history in the $15 \mathrm{M}$ movement. Equally interesting, as he points out in his extensive urban ethnography, is the established connection between stencils depicting scissors used by the antiausterity movement in Spain and the abortive coup of 1981, capitalising on the acoustic resemblance between tijeretazos (cuts) and Tejero (the name of the lieutenant-general who executed the failed coup). ${ }^{6}$ So, present-day social movements tend to act as "mnemonic agents", 7 pointing not only to a structural and organic connection between the political transitions and the current crisis, but also an affinity in terms of historical poetics. ${ }^{8}$ To quote historian Kostis Karpozilos, however, this could suggest, more than simply a revisiting and reappropriation of the past, an entrapment of leftwing protesters in history and past historical frames. ${ }^{9}$

Of course, the return to the past does not happen only in terms of antiausterity or leftwing politics and the parallel resurgence of the memory of Nazi Germany. The extreme right and a nostalgia for the military regimes expressed by a generation which did not directly experience them are also on the rise. The political stability that was achieved through repression, and the economic boom of the "long 1960s" - which stands in stark contrast to the current recession - are but two factors that contribute to this nostalgia. The dictatorship period re-emerges sanitised in the minds of some, and not only on the extreme right, as a utopian past of stability and order. For instance, at a 2012 conference in Vancouver on the current crisis, former Portuguese economy and labour minister Álvaro Pereira went as far as to praise the austerity and self-control of the late Salazar regime, as opposed to the profligate nature of postdictatorship elites..$^{10}$ Along similar lines, a growing mass of public intellectuals in Greece claim that the post-1974 condition or metapolitefsi established a negative paradigm of clientelism, corruption and political violence, as Antonis Liakos and Hara Kouki note in their piece on the discourses on the Greek crisis; the ongoing crisis is understood, in their view, as a by-product of national history and entrenched local traditions - the history of a "failed transition" since 1974 to postwar European modernity. In fact, Nikiforos Diamandouros, who was a prominent transition studies expert in the 1980s and 1990s working on comparative projects on the European South," was, at the same time, a major proponent of Greek "cultural dualism" and the country's supposedly dominant underdog culture.

But if local actors tend to now look at the transitions and the political systems that resulted from the democratic consolidations as failures, this also applies to external observers, who often attribute the latter to the establishment of a flawed socioeconomic model. A controversial report, for instance, compiled by JP Morgan in the summer of 2013 entitled "The Euro area adjustment", concluded that: "The political systems in the periphery were established in the aftermath of dictatorship, and were defined by that experience. Constitutions tend to show a strong socialist influence, reflecting the political strength that left wing parties gained after the defeat of fascism." ${ }^{12} \mathrm{It}$ is clear that the connections between past and present are discernible to a number of actors - for whom 
the recent past becomes a central issue of contention. If the imperatives of the European Economic Community in the 1980s and European Union in the 1990s had created more distance from the memory and practice of the insular dictatorships of the 1970s, the contemporary European crisis has created, unwillingly, favourable conditions for revisiting them.

All these issues pose vital questions concerning the limits of transition studies so far. This field of study, widely known as transitology, which appeared in the 1970s, with the Carnation revolution in Portugal in 1974, and was consolidated in the late 1980s, with the collapse of the communist regimes of Eastern Europe, created a list of criteria for evaluating whether a transition was smooth or not, sufficient or less sufficient, before proceeding to analyse the democratic consolidation processes. Being often synchronic to the events, however, these studies inevitably adopted a microhistorical approach, failing both to deal with longue durée issues on the temporal boundaries of transitions, and to foresee their long-term effects. Moreover, at times they put forward an extreme form of political causality and regarded the paths to democracy as predetermined, a fact that tainted transitology with a certain teleology. In his piece, Leonardo Morlino summarises precisely the achievements and failures of transition theory; by looking at the state of the art, he provides a synthetic overview of the field of comparative democratisation, identifying recurrent patterns. In a more empirical manner, furthermore, the rest of the contributions point out the various shortcomings of transitology, which can also be discerned in practice.

Another impetus behind the compilation of this volume was to relate the European - that is the Western - experience, to that of Asia, the Americas and Africa. The uprisings that shook a number of Arab countries in 2011 - which became known as the "Arab Spring" - revived some of the central questions of what constitutes a smooth passage to democratic rule after decades of authoritarianism, and whether their engines are the masses or the elites. Moreover, they force us to shift our focus from such issues as the so-called pacted or imposed transitions to the ambiguities and bifurcations of these processes and to rather neglected matters, such as the role of radical youth cultures and social movements, new social actors and emerging political subjectivities. ${ }^{13} \mathrm{It}$ remains to be established whether the political learnings drawn from the "showcase models" of transition in southern Europe, Latin America or in Eastern Europe since 1989 could be "applied" to such different contexts at present. ${ }^{14}$ Interestingly, moreover, the Arab Spring revived the question of popular revolutions and the capacity of the popular sector to trigger, rather than to just follow, democratic transitions, as is usually the case. In his contribution on the Arab Spring, Benoît Challand tackles this issue and questions whether scholars can indeed now include the Arab worlds in their "transitology dataset" and thus renew future social research on the field. In this sense, and since the indignados movements were also inspired by Tahrir Square, a supposed "peripheral" paradigm at present cross-fertilises both Western theory and action, in the same way in which revolutions in the so-called Third World gave the tenor to occidental thinkers and revolutionaries in the 1960s. Furthermore, his article brings forward the role of social classes in the transitional processes, thus reconnecting the thread with the 1970s and the influential Marxist analysis of southern European transitions of the time by the then leading theorist Nicos Poulantzas. ${ }^{15}$

Equally crucial in the re-examination of democratic transitions is the role of institutions. International institutions such as the European Union - as the then EEC - and the impact they had on the 
transition to democracy in southern European countries is often arguably overstated as a framework that was used to consolidate and stabilise the democratisation process; the same applies to $1989 .{ }^{16}$ Once again, the current eurozone crisis marks the end of a parable. ${ }^{17}$ If in the 1980s and 1990 s the historiographical debate concentrated on how Europe reinforced democratic consolidation, now with the euro crisis the debate on Europeanisation has taken a whole different direction, with its positive undertones considerably weakened (in particular after the dramatic negotiations that followed the Greek referendum in July 2015, leading to a third Greek bailout). A major factor in the discussion on institutions are the international nongovernmental foundations and their role in transitions - notably the West German party-based Stiftungen in Spain and Portugal in the 1970s and the "foreign aid" agencies and NGOs "promoting democracy" in Eastern Europe since 1989.

Local institutions, on the other hand, and in particular developments within the army, police and judiciary in the post-transitional phase, constitute issues that remain taboo in many of the countries studied in this volume. Linked to this is the conjunctural nature of transitional justice and the transformations that have taken place in this area, regardless of whether lustration, amnesty or reconciliation processes took place or not. Following Augusto Pinochet's arrest in London and the attempt to extradite him in 1998, the boundaries between international and domestic agents in terms of transitional justice became blurred, mainly thanks to the instrumental role played by controversial Spanish judge Baltasar Garzón. Local and national cultures and particularities continue to play a predominant role, however, as Raluca Grosescu stresses in her piece on transitional justice, where she debunks standard normative assumptions promoted by transitology about social phenomena. Yet, to date scholars interested in transitional justice have gone furthest in challenging the notion of velvet transitions. ${ }^{18}$

A thorny issue in the study of transitions, thus far, has to do with the use of purely structural criteria. To paraphrase E.P. Thompson, it is imperative to save many ordinary men and women of all countries in question (be it southern Europe in the 1970s, Latin America in the 1980s or post-1989 Eastern Europe) from the condescension of many transitologists, for whom the demos was peripheral to the political process. ${ }^{19}$ How would we reconstruct the events if we were to apply a bottom-up rather than a top-down approach in our attempts to historicise them $?^{20}$ And, by extension, how would we reconstruct the intensity of the experience of these very dramatic changes taking place in a very short period of time? In other words, the volume showcases the desperate need to approach the social history of the transitions, tackling the "actor versus structure" conundrum. Ideally, and to quote pioneering transitologist Philippe Schmitter, we should reach the point to account for both the role of "uncertainty" and "agency" in transitional processes - corresponding to Niccolò Machiavelli's concepts of "fortuna" and "virtù". ${ }^{21}$

According to sociologist Klaus Offe, transitions do not only constitute a move "from authoritarianism" and "to democracy" - two processes not necessarily interconnected - but also from a certain territory to another and from a certain form of economy to another (after 1989 from a statist economy to a market one). ${ }^{22}$ In their comparative piece on the political economy of the Romanian and Spanish transitions, Cornel Ban and Jorge Tamames deal precisely with the role of structural economic conditions in the collapse of authoritarian regimes. They showcase how endogenous regime factors interacted with complex economic transformations, structured by the oil and debt crises of 
the mid-1970s and early 1980s, respectively, ultimately leading to the downfall of the Ceausescu regime in Romania and the Franco regime in Spain. They also highlight the long-term economic effects of democratic transitions that the literature, which focuses instead on the short-term dynamics of these transformations, usually fails to take into account. Nevertheless, one should also stress here Schmitter and Karl's conclusion that, despite the fact that postauthoritarian democracies produce more open societies, they do not necessarily generate more open economies than the dictatorial regimes they replace. ${ }^{23}$

The issue of violence is also essential, as Challand's article highlights. It further underlines the continuities, rather than the ruptures, in the democratisation process: in terms of both Greece and Spain, for instance, violent groupings, such as ETA and 17 November, outlived the transitions, to a large extent capitalising on the armed resistance during the dictatorship years. At the same time, a large number of state-induced casualties in contentious actions characterised the transitions in the two countries. How have these violent histories and the collective memory thereof been framed and reframed since? In the case of Portugal, by contrast, the standard narrative of the revolution and the transition refers to a very peaceful process, without taking into account the twelve years of continuous violence in a bloody decolonisation war in Africa, which is conveniently glossed over. ${ }^{24}$ Different forms of extrajudicial retribution also undermined the "velvet" transition model in ex-communist Europe. There has been oblivion regarding these issues, as collective amnesia was often chosen as a means of Vergangenheitsbewältigung, though they are re-emerging powerfully in the present juncture, despite or maybe because of the absence of coherent public memory projects. All this culminates in the central question of which aspects of the democratic transitions we choose to remember, which ones we forget, and why?

In Argentina after the economic collapse of 2001, the body politic became strongly engaged in not only tackling but actively working through its painful dictatorial past, with the full support of the Kirchner government. ${ }^{25}$ In Europe, too, the great economic recession has led to the gradual re-examination of postauthoritarian structures and processes - the so-called second wave of dealing with the past, in this case in opposition to the proausterity governments of the day. It is the very change in the socioeconomic model and the political paradigm that dictated this re-evaluation of the transitions and the questioning of the quality of democracy itself. Furthermore, social movements from below often acted as carriers of revisionism regarding transitional processes as smooth, unproblematic and efficient.

Bringing together multiple disciplines, such as history, political science, political economy, historical sociology and cultural studies, and various generations of researchers, this special issue intends to offer its own contribution to this debate, marrying sociological and institutionalist approaches with culturalist ones. It further links transitions in terms of both time and space, as the volume deals with the current reappraisal of the southern European paradigm of the mid-1970s, the post-1989 transformations, the effects of Southern Cone democratisations and the 2011 revolts in the Arab worlds, thus resisting both temporal particularities and national exceptionalisms. ${ }^{26}$ Each of the various articles - different in nature, methodology and scope - stress in their own way the underlying interconnections between politics and academic research, as well as theory and practice. Finally, the volume promotes a more intense and timely dialogue between the not-so-distant 
past and the disruptive present, because no matter how complete democratisations are considered to be, historical processes resist "being frozen", as historian Berber Bevernage concludes, simply because they always contain "delays, survivals, and unfinished projects". ${ }^{27}$

\section{Kostis Kornetis}

\section{NOTES}

1 Samuel Huntington, The Third Wave: Democratization in the Late Twentieth Century (Norman: University of Oklahoma Press, 1991).

2 See, especially on the canonisation of the Spanish case, the classic works by Juan J. Linz and Alfred Stepan, The Breakdown of Democratic Regimes (Baltimore: Johns Hopkins University Press, 1978) and Problems of Democratic Transition and Consolidation (Baltimore: Johns Hopkins University Press, 1996). See also Guillermo O'Donnell, Philippe C. Schmitter and Lawrence Whitehead, eds., Transitions from Authoritarian Rule: Comparative Perspectives (Baltimore: Johns Hopkins University Press, 1986).

3 See Felipe Aguero, "Toward Civilian Supremacy in South America," in Consolidating the Third Wave Democracies: Themes and Perspectives, eds. Larry Diamond, Marc Plattner and Hung-mao Tien (Baltimore: Johns Hopkins University Press, 1997).

4 Pierre Nora, "Between Memory and History: Les Lieux de Mémoire," Representations 26 (1989): 15. See also Kostis Kornetis, “'Is There a Future in this Past?': Analysing 15M's Intricate Relation to the Transición," Journal of Spanish Cultural Studies 15/1-2 (2014): 83-98.

5 On the concept of authoritarian legacies, see Katherine Hite and Paola Cesarini, "Introducing the Concept of Authoritarian Legacies," in Authoritarian Legacies and Democracy in Latin America and Southern Europe, eds. Katherine Hite and Paola Cesarini, 1-24 (Notre Dame: University of Notre Dame Press, 2004). Of particular interest is the differentiation that Hite and Cesarini make between legacies that are interpreted as being the result of societal inertia versus the ones that are the product of political agency - which in their view is much more convincing (6).

6 The exceptional length of Labrador Méndez's article reflects the abundance of primary sources collected by the author, his rich use of images and a body of exhaustive research, linking past and present, that could not be easily reduced without compromising its substance and overall contribution.

7 Lorenzo Zamponi, "Collective Memory and Social Movements," in The Wiley-Blackwell Encyclopedia of Social and Political Movements, eds. David A. Snow, Donatella Della Porta, Bert Klandermans et al. (London: Wiley-Blackwell, 2013).

8 Of particular interest in terms of an artistic use of the poetic-popular archive of the 1970s was a recent "memory performance" by Portuguese artist Joana Craveiro that stressed the relevance of small-scale family histories and of the forgotten memories of everyday life for present, large-scale events - in this case, of the "lost archives, small memory and individual agents of history" of the Carnation Revolution in Portugal and its aftermath. See Joana Craveiro, "When was the revolution over? Memories of the transition process after the April Revolution," performative lecture at the Centre for Advanced Studies, University of Coimbra, 8 Oct. 2013.

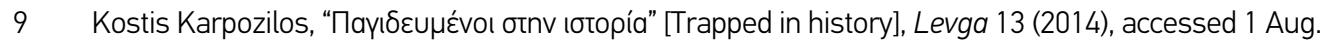
2015, http://www.levga.gr/2014/02/blog-post_17.html. 
10 Roundtable discussion at the conference on Debt, Sovereignty, and Civil Society, Simon Fraser University, 26 Apr. 2012.

11 See, for instance, Richard Gunther, Nikiforos Diamandouros, Hans-Jürgen Puhle, The Politics of Democratic Consolidation: Southern Europe in Comparative Perspective (Baltimore: Johns Hopkins University Press, 1995).

12 JP Morgan, "The Euro area adjustment: about halfway there," 28 May 2013, last accessed 1 Aug. 2015, https://culturaliberta.files.wordpress.com/2013/06/jpm-the-euro-area-adjustment-about-halfwaythere.pdf.

13 See, on this issue, Kostis Kornetis, "1968, 1989, 2011: Reconsidering Social Movements, 'Moments of Change' and Theoretical Framing Over Time," Historein 13 (2013): 58-70 and Magid Shihade, Cristina Flesher Fominaya and Laurence Cox, "The Season of Revolution: The Arab Spring and European Mobilizations," Interface 4/1 (2012): 1-16.

14 On the issue of political learning, see the classic work by Nancy Bermeo, "Democracy and the Lessons of Dictatorship," Comparative Politics 24/3 (1992): 273-291.

15 Nicos Poulantzas, The Crisis of the Dictatorships: Portugal, Spain, Greece (London: Humanities Press, 1976).

16 See, for instance, Geoffrey Pridham, ed., Encouraging Democracy: The International Context of Regime Transition in Southern Europe (Leicester: Leicester University Press, 1991) and Laurence Whitehead, ed., The International Dimensions of Democratization: Europe and the Americas (Oxford: Oxford University Press, 1996). In terms of the Greek accession to the EEC, see the more recent work by Eirini Karamouzi, Greece, the EEC and the Cold War 1974-1979: The Second Enlargement (Basingstoke: Palgrave Macmillan, 2014).

17 If the crisis within the eurozone was at first presented as a problem of the so-called PIIGS, however, which could be solved through technocratic measures alone, the current conundrum triggered by the Syriza government's collision with the European leadership signalled a degree of much needed politicisation of the euro debate. Germany's will for hegemony and clumsy power politics has, significantly, been underlined by Jürgen Habermas. See Philip Oltermann, “Jürgen Habermas's verdict on the EU/ Greece debt deal: full transcript," Guardian, 16 Jul. 2015, accessed 1 Aug. 2015, http://www.theguardian.com/commentisfree/2015/jul/16/jurgen-habermas-eu-greece-debt-deal.

18 See, for instance, Paloma Aguilar Fernández, “Justicia, politica y memoria: Los legados del franquismo en la transición española," in La política hacia el pasado: Juicios, depuraciónes, perdon y olvido en las nuevas democracias, eds. Alexandra Barahona de Brito, Paloma Aguilar Fernández and Carmen González Enríquez, 135-194 (Madrid: Istmo, 2002); losif Kovras, Truth Recovery and Transitional Justice: Deferring Human Rights Issues (London: Routledge, 2014); and Nico Wouters, ed., Transitional Justice and Memory in Europe (1945-2013) (Cambridge: Intersentia, 2014).

19 Nigel Townson, "Introduction," in Spain Transformed: The Franco Dictatorship, 1959-1975 (Basingstoke: Palgrave Macmillan, 2010), 20.

20 For some notable exceptions to the tendency of the research on the transition from dictatorship to democracy in Southern Europe in the 1970s to concentrate on "high politics", see Pamela Beth Radcliff, Making Democratic Citizens in Spain: Civil Society and the Popular Origins of the Transition, 1960-78 (Basingstoke: Palgrave Macmillan, 2011); Townson, ed., Spain Transformed; Robert M. Fishman and Omar Lizardo, “How Macro-historical Change Shapes Cultural Taste: Legacies of Democratization in Spain and Portugal," American Sociological Review 78/2 (2013): 213-239; Pedro Ramos-Pinto, Lisbon 
Rising: Urban Social Movements in the Portuguese Revolution, 1974-75 (Manchester: Manchester University Press, 2013); Nikolaos Papadogiannis, Militant Around the Clock? Left-wing Youth Politics, Leisure and Sexuality in Post-dictatorship Greece, 1974-1981 (New York: Berghahn, 2015). Also see Kostis Kornetis, Eirini Kotsovili and Nikolaos Papadogiannis, eds., Consumption and Gender in Southern Europe since the "Long 1960s" (London: Bloomsbury, forthcoming).

21 Philippe C. Schmitter, "Reflections on 'Transitology' - Before and After," in Reflections on Uneven Democracies: The Legacy of Guillermo O'Donnell, eds. Daniel M. Brinks, Marcelo Leiras and Scott Mainwaring, 71-86 (Baltimore: Johns Hopkins University Press, 2014). Schmitter quotes Machiavelli's 1535 The Prince, trans. Harvey Mansfield (Chicago: University of Chicago Press, 1985).

22 Klaus Offe, "Capitalism by Democratic Design? Democratic Theory facing the Triple Transition in East Central Europe," Social Research 58/4 (1991): 865-892.

23 Philippe C. Schmitter and Terry Lynn Karl, "What Democracy Is... And Is Not," Journal of Democracy 2/3 (1991): 86.

24 Raquel Varela, História do povo na revoluçáo portuguesa, 1974-1975 (Lisbon: Bertrand, 2013).

25 See, in this respect, Katherine Hite, Politics and the Art of Commemoration: Memorials to Struggle in Latin America and Spain (London: Routledge, 2012). Chile recently witnessed an explosion in terms of the painful memory of the Pinochet dictatorship and a parallel reconsideration of its own transition in the late 1980s.

26 A further recent attempt to link transitions in terms of time and space was attempted by scholars from the universities of Leuven, Exeter and Complutense in Madrid at a conference titled Entangled Transitions: Between Eastern and Southern Europe, 1960s-2014, 8-10 December 2014, Leuven. See http://1989after1989.exeter.ac.uk/events/conferences/entangled-transitions-dec-2014/ (accessed 11 Aug. 2015).

27 Berber Bevernage, "Time, Presence, and Historical Injustice," History and Theory 47/2 (2008): 166. 